\title{
How much energy do sick neonatal foals require compared with healthy foals?
}

\author{
Jennifer C. Ousey, N. Holdstock, P. D. Rossdale and A. J. McArthur*
}

Beaufort Cottage Stables, High Street, Newmarket, UK

${ }^{*}$ Dept. of Physics, University of the South Pacific, Suva, FIJI.

\begin{abstract}
Summary
The daily energy (E) balance of 6 healthy and 5 sick foals was measured on days 2, 4 and 7 post partum. The mean gross energy intake (GE) of the healthy foals increased from $29.7 \mathrm{MJ} \mathrm{d}^{-1}$ (day 2) to $32.8 \mathrm{MJ} \mathrm{d}^{-1}$ (day 7). Metabolisable energy (ME) was between 97 and $99 \% \mathrm{GE}$. Energy expenditure averaged $15.2,16.7$ and $19.0 \mathrm{MJ} \mathrm{d}^{-1}$ on days 2, 4 and 7 post partum, respectively. The healthy foals were in positive $E$ balance and their mean body mass increased. For the sick foals, GE intake and E expenditure were low (mean $7.2 \mathrm{MJ} \mathrm{d}^{-1}$ and $10.6 \mathrm{MJ} \mathrm{d}^{-1}$, respectively) and ME was between 90 and $99 \%$ GE. Despite their low rates of metabolism, the sick foals were in negative $E$ balance and they consumed insufficient energy to meet metabolic demand.
\end{abstract}

keywords: $\quad$ energy balance, metabolic rate, neonatal foals, sick foals.

\section{Wieviel Energie benötigen kranke Fohlen im Vergleich zu gesunden ?}

Am 2., 4. und 7. Tag post natum wurde die tägliche Energiebilanz von 6 gesunden und 5 kranken Fohlen gemessen. Die mittlere Bruttoenergieaufnahme pro Tag stieg bei den gesunden Fohlen von 29,7 MJ am 2. Tag auf 32,8 MJ am 7. Tag. Die umsetzbare Energie erreichte 97-99\% der Bruttoenergie. Die tägliche Energieabgabe betrug am 2., 4. und 7. Tag 15,2, 16,7 und $19 \mathrm{MJ}$. Die gesunden Fohlen blieben bei einer positiven Energiebilanz und nahmen an Gewicht zu. Bei den kranken Fohlen lag die tägliche Bruttoenergieaufnahme bei 7,2 MJ, die Energieabgabe erreichte 10,6 MJ. Die umsetzbare Energie erreichte 90-99\% der Bruttoenergie. Trotz der geringen Stoffwechselrate blieben die kranken Fohlen in einer negativen Energiebilanz und nahmen zu wenig Energie auf, um ihren Bedarf zu decken.

Schlüsselwörter: Energiebilanz, Stoffwechselrate, neugeborene Fohlen, kranke Fohlen

\section{Introduction}

The energy balance of a neonate governs its rate of growth and development. To achieve growth, energy intake must exceed metabolic energy expenditure and the energy lost as feces and urine. In neonatal foals, energy intake is exclusively via mares' milk. During the first 3 weeks post partum healthy foals consume between 12 and 20 $\mathrm{kg}$ milk $\mathrm{d}^{-1}$, or approximately $23-28 \%$ of their body weight as milk (Doreau and Dussap 1980; Oftedal et al. 1983; Martin et al. 1992). Similarly, measurements of free choice milk intakes by sick foals recovering from illness suggest that they consume an amount equivalent to 20-28\% of their body weight per day (Koterba and Drummond 1985; Koterba 1991).

The metabolic rates of healthy foals have been measured (Ousey et al. 1991). Rates of energy metabolism usually increase following illness or injury (Biesel 1975; Long et al. 1979). For example, in adult man the resting metabolic rate can increase by up to $80 \%$ following multiple fractures, sepsis or major burns (Long 1977; Jéquier 1987). However in infants, illness is not always associated with this hypermetabolic state. Babies suffering from hypergly- caemia, severe jaundice or prematurity have lower rates of oxygen consumption than healthy, full term infants (Brück 1961; Scopes and Ahmed 1966; Hey 1969; Mestyán 1978). In contrast, infants with respiratory illness, or following major surgery, or small-for-gestational age, have high resting rates of oxygen consumption compared with healthy infants which are an appropriate size for their gestational age (Scopes and Ahmed 1966; Hey 1969; Sinclair 1970; Chessex et al. 1984; Billeaud et al. 1992; Picaud et al. 1994; Wahlig et al. 1994; Wilson and McClure 1994). For comparison, premature foals and those suffering from neonatal maladjustment syndrome have lower metabolic rates than healthy foals of a similar post-natal age and exposed to the same range of air temperatures (Ousey et al. 1996).

The energy $(E)$ requirements of neonatal healthy and sick foals have not been documented in detail. Calculations based on the free choice intake of healthy orphaned foals, and data extrapolated from infants, indicate that foals should consume daily approximately 540-630 $\mathrm{kJ}$ (130-150 kcal) kg-1 which, for a $50 \mathrm{~kg}$ foal, is equivalent 
to 12-13 litres of milk or 27-31 MJ gross energy (Koterba 1990). However, it is not known how efficiently this energy is utilised, particularly by sick foals in which gastrointestinal (Gl) problems occur frequently (Palmer 1985; Wilson and Cudd 1990). The aims of this study were 1) to measure energy intake, metabolism and loss in both healthy and sick neonatal foals, and to determine how effectively the energy intake is utilised; and 2) to establish protocols for the E requirements of sick foals.

\section{Materials and methods}

\section{Energy intake}

Healthy foals: 5 multiparous Thoroughbred (TB) mares were studied on days 2, 4 and 7 post partum. Milk (energy) production, which is assumed to equal the foals' milk (energy) intake, was measured over $8 \mathrm{~h}$ periods. Alternate sides of the udder were milked by hand every $2-3 \mathrm{~h}$, concomitant with the foal sucking and using oxytocin iv (Ousey et al. 1996). At each milking, a milk sample was retained for subsequent energy analysis.

Sick foals: 5 sick TB foals were studied once during the first 8 days post partum. These foals were fed either mares' milk or milk replacer via a bottle or nasogastric tube. The total volume of milk consumed, litres (L), was recorded over the study periods which ranged from $17-24 \mathrm{~h}$. A sample of mares' milk, and of the 2 milk replacers, were retained for energy analysis.

\section{Energy loss and expenditure}

Healthy foals: Because the milking procedure may have disrupted the foals' energy intakes, the energy balance of a separate group of 6 healthy TB or TB cross foals was studied over $8 \mathrm{~h}$ periods on days 2, 4 and 7 post partum. Before each study, the foals were weighed. Urine and feces were collected and samples stored for energy analysis. The rate of energy expenditure (kW) was determined by open-circuit, respiration calorimetry (Ousey 1992). The foals' respiratory gases were collected over a $5 \mathrm{~min}$ period on 6 occasions during the $8 \mathrm{~h}$ when they were recumbent and when they were standing. The total periods (min) the foals spent recumbent or standing were recorded. Air temperature in the loose box was measured by a mercury-in-glass thermometer.

Sick foals: The methods were identical to those described for healthy foals. It was not possible to measure oxygen consumption by 2 sick foals. One of these foals (HS) remained recumbent throughout the study period due to sedation, and its energy expenditure was estimated from values for sick, sedated foals (Ousey et al. 1996).

\section{Analyses}

The milk and fecal samples were dried, weighed and their energy content determined by complete combustion in a Parr adiabatic bomb calorimeter. The urine energy content was determined from the concentration (mol) of urea and creatinine in each sample, measured by spectrophotometry, and their respective heats of combustion (urea, $632 \mathrm{~kJ}$ mol-1 $^{-1}$ creatinine, $2337 \mathrm{~kJ} \mathrm{~mol}^{-1}$; Blaxter 1989).

\section{Calculations}

The amount of milk obtained from one side of the udder was doubled to give total milk production over $8 \mathrm{~h}$. The energy contents (MJ) of the milk, urine and feces, were calculated by multiplying the energy content per unit mass of each sample by its corresponding mass. Values were summed to give the energy intake and loss over $8 \mathrm{~h}$. Energy expenditure $(8 \mathrm{~h})$ for each foal was determined from its mean metabolic rate $(\mathrm{kW})$, when recumbent or when standing, multiplied by the corresponding period (s) spent recumbent or standing. All energy values are expressed in units of $\mathrm{MJ} \mathrm{d}^{-1}$.

The energy available for growth (NEg) was calculated as follows:

$$
\mathrm{NEg}=\mathrm{GE}-\mathrm{FE}-\mathrm{UE}-\mathrm{NEm}
$$

where GE is the gross energy intake from milk and other fluids (eg iv glucose), FE is the energy content of feces, $\mathrm{UE}$ is the energy content of urine and NEm is the energy expenditure. The quantity (GE-FE-UE) is usually termed metabolisable energy (ME). The term NEm includes energy utilised for maintenance (ie. basal metabolism, activity and thermoregulation) and the energy loss associated with feeding. Energy lost via the gaseous products of digestion were assumed to be negligible in young foals and, therefore, were not measured.

\section{Results}

Table 1 gives the gestational age, times to first stand and suck, energy source and outcome for both groups of foals. The healthy foals ( 3 colts, 3 fillies) were delivered spontaneously at full term, and stood and sucked within the normal time $(<2.5 \mathrm{~h})$. They had normal haematological profiles and $\operatorname{lgG}$ concentrations (mean $11.8 \mathrm{~g} \mathrm{~L}^{-1}$ ) on day 2 post partum. The sick foals ( 1 colt, 4 fillies) suffered from either prematurity (AR, HV, SS) or neonatal maladjustment syndrome (PO, HS) following birth asphyxia or hypoxia. All needed veterinary assistance and intensive care for several days. All had a good suck reflex but were either too weak or uncoordinated to stand and suck from their dams. Consequently, the sick foals were fed via either a bottle, and / or a nasogastric tube. Three sick foals received mares' milk and/or milk replacer, and 2 received mares' milk, and glucose iv. Additional iv. fluids $10.9 \%$ saline, 4.2\% bicarbonate, Hartmann's solution, mare's plasma) were also given according to clinical needs.

Table 2 shows the mean $( \pm \mathrm{sd}$ ) energy balance components (equation 1) for the healthy foals. Their mean daily energy intake increased gradually with time but the energy intake per unit mass of foal decreased. FE was low 
Tab. 1: Comparison of healthy and sick foals: type of delivery and gestational age, time to first stand and suck from the dam without assistance, feeding regime and foal outcome.

Vergleich gesunder und kranker Fohlen: Art der Geburt, Tragezeit, Zeit bis zum ersten Aufstehen und Saugen bei der Stute ohne Hilfe, Fütterungsregime und weiterer Verlauf

\begin{tabular}{|l|l|l|l|l|l|l|}
\hline \multirow{2}{*}{ Criteria } & Healthy & \multicolumn{5}{|c|}{ Sick foals $\mathrm{n}=5$} \\
& $\mathrm{n}=6$ & $\mathrm{AR}$ & $\mathrm{HV}$ & $\mathrm{HS}$ & $\mathrm{PO}$ & $\mathrm{SS}$ \\
\hline Delivery & $\mathrm{Sp}$ & $\mathrm{Sp}$ & $\mathrm{Sp}$ & $\mathrm{Sp}$ & $\mathrm{Sp}$ & $\mathrm{CS}$ \\
\hline Gestation (d) & 335 & 307 & 270 & 325 & 361 & 334 \\
\hline First stand (h) & $<1$ & Never & 2 & 1.5 & 10 & 21 \\
\hline First suck (h) & $<2.5$ & Never* & 150 & Never & Never & Never \\
\hline Energy source & Mare & $\begin{array}{l}\text { Mare / } \\
\text { Gluc. iv }\end{array}$ & $\begin{array}{l}\text { Mare } / \\
\text { MRep }\end{array}$ & Mare & $\begin{array}{l}\text { Mare / } \\
\text { Gluc. iv }\end{array}$ & MRep \\
\hline Feed method & Mare & Bottle & Bottle & NG tube & Bottle / \\
NG tube & Bottle \\
\hline Outcome & Lived & Eu-28 d & Lived & Eu-4 d & Eu-5 d & Lived \\
\hline
\end{tabular}

* Foal was orphaned.

$\mathrm{Sp}=$ spontaneous; $\mathrm{CS}=$ Caesarian Section; $\mathrm{Eu}=$ euthanasia; Gluc. iv = intravenous glucose; MRep = milk replacer; NG tube = nasogastric tube.

and increased concurrent with an increase in the mass of feces produced (dry mass $=8.1 \mathrm{~g}$ [day 2]; $20.6 \mathrm{~g}$ [day 4]; $41.6 \mathrm{~g}$ [day 7 ]). For each study period, 4 healthy foals

Tab. 2: Energy balance of healthy foals: daily mean ( $\pm \mathrm{sd}$ ) values of energy intake, energy loss (feces and urine), energy expenditure, net energy for growth, and body mass on days 2,4 and 7 days post partum.

Energiebilanz gesunder Fohlen am 2., 4. und 7. Lebenstag: durchschnittliche tägliche Energieaufnahme $( \pm \mathrm{s})$, Energieverluste (Kot, Harn), Energieabgabe, Nettoenergie für Wachstum und Körpergewicht

\begin{tabular}{|c|c|c|c|}
\hline Energy & Day 2 & Day 4 & Day 7 \\
\hline $\begin{array}{r}\text { Milk intake, GE } \quad(M J) \\
(\mathrm{ml} \mathrm{kg}-1) \\
(\mathrm{kJ} \mathrm{kg}-1)\end{array}$ & $\begin{array}{l}29.7 \pm 4.3 \\
231 \\
593\end{array}$ & $\begin{array}{l}30.3 \pm 5.9 \\
232 \\
573\end{array}$ & $\begin{array}{l}32.8 \pm 8.3 \\
224 \\
544\end{array}$ \\
\hline $\begin{array}{ll}\text { Loss-feces, FE } & \text { (MJ) } \\
\text { Loss-urine, UE } & \text { (MJ) }\end{array}$ & $\begin{array}{l}0.12 \pm .27 \\
0.16 \pm .04\end{array}$ & $\begin{array}{l}0.49 \pm .78 \\
0.14 \pm .04\end{array}$ & $\begin{array}{l}0.94 \pm 1.8 \\
0.15 \pm .07\end{array}$ \\
\hline Urine produced & $6.8 \pm 2.1$ & $9.3 \pm 2.0$ & $10.0 \pm 3.1$ \\
\hline$(\mathrm{MJ})$ & 29.4 & 29.7 & 31.7 \\
\hline (as \% GE) & 99 & 98 & 97 \\
\hline $\begin{array}{r}\text { Expenditure, NEm (MJ) } \\
(\mathrm{kJ} \mathrm{kg-1)}\end{array}$ & $\begin{array}{l}15.2 \pm 3.5 \\
307 \pm 26\end{array}$ & $\begin{array}{l}16.7 \pm 3.9 \\
318 \pm 24\end{array}$ & $\begin{array}{l}19.0 \pm 3.7 \\
319 \pm 37\end{array}$ \\
\hline 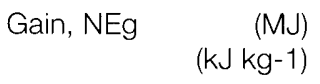 & $\begin{array}{l}14.3 \\
285\end{array}$ & $\begin{array}{l}13.0 \\
246\end{array}$ & $\begin{array}{l}12.7 \\
210\end{array}$ \\
\hline Body mass & $50.1 \pm 13.5$ & $52.9 \pm 13.9$ & $60.3 \pm 13.4$ \\
\hline
\end{tabular}

For abbreviations see text (equation 1). produced no feces during the $8 \mathrm{~h}$ sampling period. One foal, on day 2, produced loose feces which were impossible to collect. The daily energy losses in urine were also low despite the copious volumes of urine produced (6-10 $\left.L d^{-1}\right)$. The ME values were high (97-99\% GE). The energy expenditure increased with time, as did the expenditure per unit body mass. The healthy foals spent, on average, $12.4 \mathrm{~h}$ standing on days 2 and 4 post partum; this value increased to $13.8 \mathrm{~h}$ by day 7 . The foals were in positive energy balance on each day and this was associated with an average mass gain of $10 \mathrm{~kg}$ between days 2 and 7 post partum. The air temperatures recorded during the study periods ranged from $7.5-25^{\circ} \mathrm{C}$. Two foals shivered when exposed to air temperatures below $18^{\circ} \mathrm{C}$, usually when they were recumbent.

Table 3 shows the energy balance components for each sick foal, including its age. Their mean daily GE was 7.2 $\mathrm{MJ}$ (range 4.9-10.9 MJ), about $25 \%$ of that for the healthy foals (Table 2). Energy intake per unit mass for the sick foals was less than $50 \%$ of that for the healthy foals. In general, the dry mass of feces (range 1.4-27.9 g) produced by the sick foals, and FE, were less than for the healthy foals. The sick foals produced between 0.1 and $3.0 \mathrm{~L} \mathrm{~d}^{-1}$ of urine, with an associated energy loss below 0.3 MJ. The ME values ranged from 90-99 \% GE. The sick foals spent a minimum of $22 \mathrm{~h}$ per day recum-

Tab. 3: Energy balance of sick foals: individual daily values of energy intake, energy loss (feces and urine), energy expenditure, net energy for growth, and body mass for 5 foals age 2-8 days post partum.

Energiebilanz kranker Fohlen am 2. bis 8. Lebenstag: tägliche Energieaufnahme, Energieverluste (Kot, Harn), Energieabgabe, Nettoenergie für Wachstum und Körpergewicht

\begin{tabular}{|c|c|c|c|c|c|}
\hline Energy & $A R$ & $\mathrm{HV}$ & HS & $\mathrm{PO}$ & SS \\
\hline (days) & 2 & 8 & 3 & 3 & 2 \\
\hline $\begin{array}{r}(\mathrm{MJ}) \\
\left(\mathrm{kJ} \mathrm{kg}^{-1}\right)\end{array}$ & $\begin{array}{l}7.2 \\
182\end{array}$ & $\begin{array}{l}7.3 \\
349\end{array}$ & $\begin{array}{l}4.9 \\
122\end{array}$ & $\begin{array}{l}10.9 \\
198\end{array}$ & $\begin{array}{l}6.1 \\
125\end{array}$ \\
\hline Oral intake & 2.5 & 3.0 & 1.9 & 3.7 & 3.8 \\
\hline iv intake & 2.0 & - & 1.6 & 3.0 & 0.39 \\
\hline Loss-feces, FE & 0.60 & 0.52 & 0.09 & 0.05 & 0.30 \\
\hline Loss-urine, UE & 0.02 & 0.22 & 0.07 & 0.10 & 0.21 \\
\hline Urine produced & 0.15 & 2.94 & 0.59 & 0.69 & 2.47 \\
\hline$(\mathrm{MJ})$ & 6.6 & 6.6 & 4.7 & 10.7 & 5.6 \\
\hline (as \% GE) & 91 & 90 & 97 & 99 & 92 \\
\hline $\begin{array}{r}\text { Expenditure, } \mathrm{NEm}(\mathrm{MJ}) \\
\left(\mathrm{KJ} \mathrm{kg}^{-1}\right)\end{array}$ & $\begin{array}{l}\text { ND } \\
\text { ND }\end{array}$ & $\begin{array}{l}9.9 \\
473\end{array}$ & $\begin{array}{l}10.5^{\star \star} \\
263\end{array}$ & $\begin{array}{l}12.3 \\
224\end{array}$ & $\begin{array}{l}9.6 \\
192\end{array}$ \\
\hline Gain, NEg & ND & - & - & - & - \\
\hline Body mass & 38 & 21 & 40 & 55 & 50 \\
\hline
\end{tabular}

For abbreviations see text (equation 1).

*includes energy from oral and iv sources; ${ }^{* *}$ estimated value; $\mathrm{ND}=$ not determined. 
bent (asleep) and, not surprisingly, their energy expenditure (mean value 10.6 $\mathrm{MJ} \mathrm{d}^{-1}$ ) was about two thirds that of the healthy foals. The data indicate that 4 sick foals were in negative energy balance; it is likely that the fifth foal (AR), for which NEm was not measured and which had the third lowest energy intake, was also in negative energy balance. Of the 2 sick foals which survived, one (HV) gained $2 \mathrm{~kg}$ during the first 2 weeks post partum. The air temperatures ranged from $9.5-26{ }^{\circ} \mathrm{C}$. The sick foals were supplied with additional "warmth" from overhead radiant heaters. Three foals wore rugs, one of which (HV) shivered when air temperatures were below $17^{\circ} \mathrm{C}$.

The gradual increase in GE with time by the healthy foals (Table 2) was associated with a corresponding increase

Tab. 4: Mean ( $\pm \mathrm{sd}$ ) rate of daily milk production and energy content for 5 Thoroughbred mares on days 2, 4 and 7 post partum.

Durchschnittliche $(x \pm s)$ tägliche Milchproduktion und Energiegehalt der Milch bei 5 Vollblutstuten am 2., 4. und 7. Laktationstag

\begin{tabular}{|l|l|l|l|}
\hline Milk & Day 2 & Day 4 & Day 7 \\
\hline Mare body mass (kg) & $564 \pm 50$ & - & - \\
\hline Production & & & \\
$(\mathrm{L})$ & $11.6 \pm 2.3$ & $12.3 \pm 2.7$ & $13.6 \pm 3.7$ \\
$(\mathrm{ml} \mathrm{kg}-1)^{\star}$ & $20.4 \pm 2.6$ & $21.6 \pm 3.4$ & $23.8 \pm 4.3$ \\
$(\mathrm{ml} \mathrm{kg}-1)^{\star \star}$ & 231 & 232 & 225 \\
$\%$ foal body mass & 23.6 & 23.8 & 23.1 \\
\hline Energy & & & \\
$($ MJ L-1) & $2.6 \pm 0.2$ & $2.5 \pm 0.2$ & $2.4 \pm 0.1$ \\
$(\text { MJ kg- } 1)^{\star \star \star}$ & $21.4 \pm 1.5$ & $20.6 \pm 0.4$ & $20.8 \pm 0.7$ \\
\hline
\end{tabular}

* based on body mass of mare

** based on body mass of foals

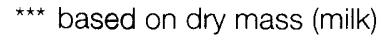

in milk intake. Table 4 shows that the mass of milk consumed daily increased and was equivalent to approximately $23 \%$ of the foals' body mass. However, as they gained weight their milk intake per unit body mass remained fairly constant at about $230 \mathrm{ml} \mathrm{kg}^{-1}$. The average energy content of the milk decreased slightly with time from 2.6 to $2.4 \mathrm{MJ} \mathrm{L}^{-1}$.

The energy contents per unit dry mass of the 2 milk replacers fed to 2 sick foals were 20.0 and $20.4 \mathrm{MJ} \mathrm{kg}^{-1}$. One foal (SS) received milk replacer at half strength (ie 10 $\mathrm{MJ} \mathrm{kg}^{-1}$ ) due to post prandial colic. A milk sample from the mare which foaled at 270 days gestation $(\mathrm{HV})$, had an energy content of $20.3 \mathrm{MJ} \mathrm{kg}^{-1}$. The sick foals received between 1.9 and $3.8 \mathrm{~L}$ of enteral fluids. Their total fluid intakes (3-6 $\mathrm{L} \mathrm{d}^{-1}$ ) were approximately one third that of the healthy foals despite parenteral administration of other fluids for clinical purposes (Table 3).

\section{Discussion}

\section{Energy intake}

The data provide detailed information on the energy balance of healthy and sick neonatal foals. The milk volumes and GE values for the healthy foals are similar in magnitude to published values (Gibbs et al. 1982; Oftedal et al. 1983; Doreau et al. 1986; Martin et al. 1992). These authors reported daily milk yields in the range $11-19 \mathrm{~kg}$ between days 7 and 18 post partum for Quarterhorses, Thoroughbreds, Standardbreds and heavy horses. They also reported daily energy intakes by the foals of between 32 and $50 \mathrm{MJ}$. There are few citations of milk and energy intakes of foals age $<7$ days. This is a critical period when foals adapt to an enteral diet, and when intensive care and artificial feeding regimes for sick foals are most likely to be implemented. Doreau and Dussap (1980) reported an average milk consumption of $16.2 \mathrm{~kg}$ (range 12-20 kg) in heavy horse foals (mean body mass $=69 \mathrm{~kg}$ ) during the first week post partum. Recommended GE values for foals of this age are approximately 520-630 kJ kg-1 $\mathrm{d}^{-1}$, or between 10-25\% of their body mass as milk (Koterba and Drummond 1985; Koterba 1990). These recommendations are similar to the measured milk energy intakes of the healthy foals in the present study.

In contrast, the milk volume and GE values for the sick foals were substantially below those of the healthy foals. Their low GE was a direct result of a decreased consumption of fluid, rather than a reduction in the energy content of either the mares' milk or the milk replacers. The fluid intakes of the sick foals were approximately equal to the minimum recommended values (about $10 \%$ body mass) but fell short of the recommended energy intakes (see above). Four sick foals were fed by bottle and, effectively, had a free choice intake. Only one of these foals (SS) had its energy intake restricted, due to previous bouts of colic post prandially. Clearly, the sick foals were incapable of, or not interested in, consuming as much milk (energy) as the healthy foals. This inability of sick neonates to consume sufficient milk may be due to gastrointestinal and other problems (Hansen 1986; Settle and Vaala 1991; Heird et al. 1992). Total parenteral nutrition (TPN) is one method used to provide energy and avoid the Gl tract, and is used frequently in premature infants (Hack et al. 1991). There is some reluctance to use TPN in foals, partly due to the expense and partly to practical problems (Cudd 1993). However, TPN is probably the only way to achieve positive energy balance in sick foals, and could be life-saving in some cases (Peek et al. 1994).

Despite an increase with time in the total milk consumption by the healthy foals, both the milk volume and energy intake, per unit body mass decreased. These decreases were due to an increase in foals' body mass and to a slight decrease in the milk energy content. (Table 4) The milk energy content is of similar magnitude to values pub- 
lished previously. Ullrey et al. (1966) and Doreau et al. (1988) reported milk energy values of between 2.4 and $2.6 \mathrm{MJ} \mathrm{kg}^{-1}$ during the first week post partum (excluding colostrum), values which declined gradually with progressive lactation. Presumably, the contribution by milk to the energy intake per unit body mass of growing foals declines as other nutrient sources take over.

\section{Energy losses}

The large volumes of dilute urine produced by young foals, and its biochemical constituents, have been documented (Brewer 1990; Broughton Pipkin et al. 1991; Holdstock 1995). However, their energy losses via urine and feces have not been reported. In this study, ME for healthy foals was high and similar to ME values for neonatal lambs, calves and piglets (91-99\% GE) reported by Blaxter (1952), Walker et al. (1967) and Le Dividich et al. (1994). However in healthy infants, ME is approximately 85-90\% GE (Reichman et al. 1982; Whyte et al. 1983; Sauer et al. 1984; Freymond et al. 1986) and can be as low as $65 \%$ GE (Brooke 1982). In adult horses, a large component (27\%) of GE is lost via the feces (Pagan and Hintz 1986). Our data suggest that FE loss is not significant in healthy, neonatal foals and that they digest milk (energy) efficiently. However, FE may have been underestimated because of the short sampling periods. We are not aware of published data with which to compare our figures on the mass of feces produced by healthy foals age less than $7 \mathrm{~d}$.

The quantities of urine and feces produced by the sick foals were generally lower than those produced by the healthy foals of the same age, and probably reflect the low milk (and fluid) intakes of the sick foals. Of the 3 sick foals which had low ME values (90-92\% GE), two (HV and SS) were fed milk replacer (Table 1). For comparison, in healthy, premature infants fed isocaloric diets of formula or breast milk, there were no differences in ME between the 2 diets (Whyte et al. 1983; Brooke et al. 1987). The digestibility of milk replacer has not been assessed previously in neonatal foals, particularly sick foals, although some authors report that healthy foals fed milk replacer experience diarrhoea, constipation or colic (King and Nequin 1989; Cymbaluk et al. 1993). In our study, one sick foal (SS) fed milk replacer had colic. Our data indicate that the digestibility of enteral feeds may be impaired in sick foals and that this condition may be exacerbated when they are fed milk replacer.

\section{Energy expenditure}

The energy expended by the healthy foals increased with age. In neonates of several species, metabolic rate increases during the early post-natal period (Hill and Rahimtulla 1965). In addition, metabolic rate is influenced by several variables, in particular the thermal environment, feeding and activity (Mount 1979; Chessex et al. 1981; Freymond et al. 1986). In our study, there were no diffe- rences in the thermal environment or feeding patterns between healthy foals of different ages. However, the foals aged 7 days stood for approximately $1 \mathrm{~h}$ longer during the study period than they did when younger. This increased activity probably contributed to the rise in energy expenditure. When recumbent, the healthy foals' metabolic rate increased by $23 \%$ between days 2 and 7 post partum. Unfortunately, the recumbent foals became resentful of the gas collections as they grew older, behaviour which may have contributed to the increment in metabolic rate (and energy expenditure) with age.

The energy expenditure ( $\mathrm{MJ} \mathrm{d}^{-1}$ ) of the sick foals was much lower than that of the healthy foals. Because several variables can affect metabolic rate it is difficult to quantify the impact of illness on metabolism. The hypermetabolic state, observed in sick infants and adults following surgery and disease, may have occurred in one sick foal $(H V)$. However, shivering during the respiratory gas collections could account for this foal's high energy expenditure (473 kJ kg-1). Ousey et al. (1992) reported that metabolic rate doubled when healthy, young pony foals were shivering at $15^{\circ} \mathrm{C}$ below their lower critical temperature. The critical temperature for sick foals has been estimated to be $24{ }^{\circ} \mathrm{C}$ (Ousey et al. 1996). It is probable, therefore, that $\mathrm{HV}$ foal had raised its metabolic rate in response to the cool air temperatures $\left(<17^{\circ} \mathrm{C}\right)$ rather than illness.

The most likely cause of the low energy expenditure by the sick foals is inactivity. They spent most of the day recumbent. If the mean daily energy expenditure per unit mass of recumbent healthy foals is calculated, then the values are 235,258 and $260 \mathrm{~kJ} \mathrm{~kg}^{-1}$ for days 2,4 and 7 post partum, respectively. These values are of similar magnitude to the rates of energy expenditure values by the sick foals in Table 3 (mean value $288 \mathrm{~kJ} \mathrm{~kg}^{-1}$ ). The low energy expenditure by sick foals may also be a consequence of the low GE. For comparison, Bhakoo and Scopes (1974) and Chessex et al. (1981) suggested that a restricted energy intake, lowers the metabolic rates of infants. Interestingly, increasing energy intake in infants appears not to raise their energy expenditure independently of diet composition and the benefits of overfeeding sick neonates have been questioned (Chwals 1994; Van Aerde et al. 1994).

\section{Energy for growth}

The healthy foals had a positive energy balance on each day of the study. The increase in their body mass $(10 \mathrm{~kg})$ from days 2-7 post partum is similar to reported values $(8 \mathrm{~kg})$ for TB foals of the same age (Hintz et al. 1979). However, activity will reduce the energy available for growth in free ranging foals below the amounts shown in Table 2. Also, exposure to cold temperatures outdoors will decrease the energy available for growth compared with horses maintained in warmer conditions indoors (Cymbaluk 1990). Therefore, the values of NEg and NEm for healthy foals in their normal environment are likely to be 
lower and higher, respectively, than the values given in Table 3.

In contrast, the energy expenditure of the sick foals exceeded GE intake in all cases in which it was measured and, therefore, energy was not available for growth. This result is confirmed by the low initial growth rate of one of the sick foals which survived. A negative energy balance indicates catabolism of existing body stores to meet metabolic demands. However, these energy stores may be negligible in the foal or diminished already, due to the high metabolic energy demands at birth or to pre-partum effects such as intra-uterine growth retardation or placental abnormalities (Fowden et al. 1991; Ousey et al. 1991). Coupled with possible increased demands for energy and protein associated with illness, the sick equine neonate is likely to suffer from undernutrition. The effects of undernutrition in foals are unknown, but data for other species indicate increased morbidity and mortality in malnourished patients (Bartlet et al. 1982; Grosdidier 1993; Wilson and McClure 1994).

Sick foals must have an adequate energy intake to avoid undernutrition. Based on the energy expenditure data of healthy recumbent foals (including a thermoregulatory component, and assuming that ME is $90 \%$ ), we recommend a gross energy intake of between 260 and $290 \mathrm{~kJ}$ $\mathrm{kg}^{-1} \mathrm{~d}^{-1}$ (equivalent to 62-69 kcal kg-1 $\mathrm{d}^{-1}$ ) for sick neonatal foals during the first week post partum. This energy intake, the minimum required to maintain metabolic equilibrium, should be used only as a guide; individual requirements may vary greatly and are best assessed by measurement of metabolic rate. To gain weight and to meet the increased energy demands associated with activity (standing), we suggest that GE should be between 540 and $600 \mathrm{~kJ} \mathrm{~kg}^{-1} \mathrm{~d}^{-1}$ (130 to $145 \mathrm{kcal} \mathrm{kg}^{-1} \mathrm{~d}^{-1}$ ), equivalent to that of healthy foals. However, the feasibility of feeding high energy diets to sick foals, and the partitioning of this energy by foals, requires further investigation.

\section{References}

Bartlet, R. H., Dechert, R. E., Mault, J. R., Ferguson, S. K., Kaiser, A. M., and Erlandson, E. E. (1982): Measurement of metabolism in multiple organ failure. Surgery $92,771-778$.

Bhakoo, O. N. and Scopes, J.W. (1974): Minimal rates of oxygen consumption in small-for-dates babies during the first week of life. Arch. Dis. Childh. 49, 583-585.

Biesel, W. R. (1975): Metabolic responses to infection. Ann. Rev. Med. 26, 9-20.

Billeaud, C., Piedboeuf, B. and Chessex, P. (1992): Energy expenditure and severity of respiratory disease in very low birth weight infants receiving long-term ventilatory support. J. Pediatr. 120, 461-464.

Blaxter, K. L. (1952): The nutrition of the young Ayrshire calf. 6. The utilisation of the energy of whole milk. Br. J. Nutr. 6, 12-19.

Blaxter, K. L. (1989): Energy Metabolism in Animals and Man. Cambridge University Press, Cambridge.

Brewer, B. D. (1990): Renal diseases. In Equine Clinical Neonatology. Eds. A.M. Koterba, W.H. Drummond, P.C. Kosch. pp. 446-458.
Brooke, O. G. (1982): Energy requirements and utilization of the low birthweight infant. Acta Paediatr. Scand. suppl. 296, 67-70.

Brooke, O. G., Onugogu, O., Heath, R. and Carter, N. D. (1987): Human milk and preterm formula compared for effects on growth and metabolism. Arch. Dis. Childh. 62, 917-923.

Broughton Pipkin, F., Ousey, J. C. and Rossdale, P. D. (1991): Observations of changing renal function in the newborn pony foal. $J$. Reprod. Fert. suppl. 44, 736-737.

Brück, K. (1961): Temperature regulation in the newborn infant. Biol. Neonate 3, 65-119.

Chessex, P., Reichman, B. L., Verellen, G. J. E., Putet, G., Smith, J. M., Heim, T. and Swyer, P. R. (1981): Influence of postnatal age, energy intake, and weight gain on energy metabolism in the very low-birth-weight infant. J. Pediatr. 99, 761-766.

Chessex, P., Reichman, B. L., Verellen, G. J. E., Putet, G., Smith, J. M., Heim, T. and Swyer, P. R. (1984): Metabolic consequences of intrauterine growth retardation in very low birthweight infants. Pediatr. Res. 18, 709-713.

Chwals, W. J. (1994): Overfeeding the critically ill child: fact or fantasy? New Horiz. 2, 147-155.

Cudd, T. A. (1993): Parenteral nutrition support in foals. Comp. Cont. Educ. Pract. Vet. 15 (11), 1547-1550.

Cymbaluk, N. F. (1990): Cold housing effects on growth and nutrient demand of young horses. J. Anim. Sci. 68, 3152-3162.

Cymbaluk, N. F., Smart, M. E., Bristol, F. M. and Ponteaux, V. A. (1993): Importance of milk replacer intake and composition in rearing orphan foals. Can. vet. J. 34, 479-486.

Doreau, M. and Dussap, G. (1980): Estimation de la production laitiere de la jument allaitante par marquage de l'eau corporelle du poulain. Reprod. Nutr. Dévelop. 20, 1883-1892.

Doreau, M., Boulot, S., Martin-Rosset, W. and Robelin, J. (1986): Relationship between nutrient intake, growth and body composition of the nursing foal. Reprod. Nutr. Dévelop. 26 (2B), 683-690.

Doreau, M., Martin-Rosset, W. and Boulot, S. (1988): Energy requirements and the feeding of mares during lactation: a review. Livestock Prod. Sci. 20, 53-68.

Fowden, A. L., Mundy, L., Ousey, J. C., McGladdery, A. J. and Silver, M. (1991): Tissue glycogen and glucose-6-phosphatase levels in fetal and newborn foals. J. Reprod. Fert. Suppl. 44, $537-542$

Freymond, D., Schutz, Y., Decombaz, J., Micheli, J-L. and Jéquier, E. (1986): Energy balance, physical activity and thermogenic effects of feeding in premature infants. Pediatr. Res. 20, 638-645.

Gibbs, P. G., Potter, G. D., Blake, R. W. and McMullan, W. C. (1982): Milk production of Quarter horse mares during the first 150 days of lactation. J. Anim. Sci. 54, 496-499.

Grosdidier, S. (1993): Critical care nutrition. Vet. Tech. 14, 59-69.

Hack, M., Horbar, J. D., Malloy, M. H., Tyson, J. E., Wright, E. and Wright, L. (1991): Very low-birth-weight outcomes of the National institutes of Child Health and Human Development Neonatal Network. Paediatrics 87, 587-597.

Hansen, T. O. (1986): Parenteral nutrition in foals. Am Ass. Equine Pract. 33, 153-156.

Hey, E. N. (1969): The relation between environmental temperature and oxygen consumption in the new-born baby. J. Physiol. 200, 589-603.

Heird, W. C., Jensen, C. L. and Gomez, M. R. (1992): Practical aspects of achieving positive energy balance in low birth weight infants. J. Pediatr. 120, 120-128.

Hill, J. R. and Rahimtulla, K. A. (1965): Heat balance and the metabolic rate of new-born babies in relation to environmental temperature; and the effect of age and weight on basal metabolic rate. J. Physiol. 180, 239-265.

Hintz, H. F., Hintz, R. L. and Van Vleck, L. D. (1979): Growth rate of Thoroughbreds. Effect of age of dam, year and month of birth, and sex of foal. J. Anim. Sci. 48, 480-487. 
Holdstock, N. B. (1995): Electrolyte and Water Homeostasis in the Perinatal Foal. PhD thesis, University of Cambridge.

Jéquier, E. (1987): Measurement of energy expenditure in clinical nutritional assessment. J. Parent. Ent. Nutr. 11, 86S-89S.

King, S.S. and Nequin, L.G. (1989): An artificial rearing method to produce optimum growth in orphaned foals. J. Equine Vet Sci. 9 319-322

Koterba, A.M. (1990): Nutritional support: enteral feeding. in Equine Clinical Neonatology. Eds. A.M. Koterba, W.H. Drummond, P.C. Kosch. pp. 728-746.

Koterba, A. M. (1991): Intravenous fluid therapy and nutritional support in the sick neonate. Equine vet. Educ. 3, 33-39.

Koterba, A. M. and Drummond, W. H. (1985): Nutritional support of the foal during intensive care. Vet. Clin. N. Am. 1 (1), 35-40.

Le Dividich, J., Herpin., P. and Rosario-Ludovino, R. M. (1994): Utilization of colostral energy by the newborn pig. J. Anim. Sci. $72,2082-2089$

Long, C. L. (1977): Energy balance and carbohydrate metabolism in infection and sepsis. Am. J. Clin. Nutr. 30, 1301-1310.

Long, C. L., Schaffel, N., Geiger, J. W., Schiller, W. R. and Blakemore, W. S. (1979): Metabolic response to injury and illness: estimation of energy and protein needs from indirect calorimetry and nitrogen balance. J. Parent. Ent. Nutr. 3, 452-456.

Martin, R. G., McMeniman, N. P. and Dowsett, K. F. (1992): Milk and water intakes of foals sucking grazing mares. Equine vet. J. $24,295-299$

Mestyán, J. (1978): Energy metabolism and substrate utilization in the newborn. In Temperature Regulation and Energy Metabolism in the Newborn. Ed. J.C. Sinclair. pp.39-74.

Mount, L. E. (1979): Adaptation to the Thermal Environment. Man and his Productive Animals. Edward Arnold, London.

Oftedal, O. T., Hintz, H. F. and Schryver, H. F. (1983): Lactation in the horse: milk composition and intake by foals. J. Nutr. 113, 2096-2106.

Ousey, J. C. (1992): Thermoregulation and energy metabolism in the newborn foal. PhD thesis, University of Nottingham, UK

Ousey, J. C., McArthur, A. J., Murgatroyd, P. R., Stewart, J. H. and Rossdale, $P$. D. (1992): Thermoregulation and total body insulation in the newborn foal. J. therm. Biol. 17, 1-10.

Ousey, J.C., MCArthur, A.J. and Rossdale, P.D. (1991): Metabolic changes in Thoroughbred and pony foals during the first $24 \mathrm{~h}$ post partum. J. Reprod. Fert., suppl. 44, 561-570.

Ousey, J. C., McArthur, A. J. and Rossdale, P. D. (1996): Thermoregulation in sick foals age less than one week. (in press).

Pagan, J. D. and Hintz, H. F. (1986): Equine energetics. 1. Relationship between body weight and energy requirements in horses. J. Anim. Sci. 63, 815-821.

Palmer, J. E. (1985): Gastrointestinal diseases of foals. Vet. Clin. N. Am. 1, 151-168.

Peek, S. F., Byars, T. D. and Rueve, E. (1994): Neonatal hepatic failure in a Thoroughbred foal: successful treatment of a case of presumptive Tyzzer's disease. Equine vet. Educ. 6, 307-309.

Picaud, J-C., Putet, G., Rigo, J., Salle, B. L. and Senterre, J. (1994): Metabolic and energy balance in small- and appropriatefor-gestational-age, very low-birth-weight infants. Acta. Paediatr. Suppl. 405, 54-59.

Reichman, B. L., Chessex, P., Putet, G., Verellen, J. E., Smith, J. M., Heim, T. and Swyer, P. R. (1982): Partition of energy metabolism and energy cost of growth in the very low-birth-weight infant. Pediatrics 69, 446-451.
Sauer, P. J. J., Dane, H. J. and Visser, H. K. A. (1984): Longitudinal studies on metabolic rate, heat loss, and energy cost of growth in low birth weight infants. Pediatr. Res. 18, 254-259.

Scopes, J. W. and Ahmed, I. (1966): Minimal rates of oxygen consumption in sick and premature newborn infants. Arch. Dis. Childh. 41, 407-416

Settle, C. S. and Vaala, W. E. (1991): Management of the critically ill foal: initial respiratory, fluid and nutritional support. Equine vet. Educ. 3, 49-54.

Sinclair, J. C. (1970): Heat production and thermoregulation in the small-for-date infant. Ped. Clin. N. Am. 17, 147-158.

Ulirey, D. E., Struthers, R. D., Hendricks, D. G. and Brent, B. E. (1966): Composition of mare's milk. J. Anim. Sci. 25, 217-222.

Van Aerde, J. E., Sauer, P. J., Pencharz, P. B., Smith, J. M., Heim, T. and Swyer, P. R. (1994): Metabolic consequences of increasing energy intake by adding lipid to parenteral nutrition in fullterm infants. Am. J. Clin. Nutr. 59, 659-662.

Wahlig, T. M., Gatto, C. W., Boros, S. J., Mammel, M. C., Mills, M. M. and Georgieff, M. K. (1994): Metabolic response of preterm infants to variable degrees of respiratory illness. J. Pediatr. 124 , 283-288.

Walker, D. M., Cook, L. J. and Jagusch, K. T. (1967): Nitrogen balance studies with the milk-fed lamb, Br. J. Nutr. 21, 275-287.

Whyte, R. K., Haslam, R., Vlainic, C., Shannon, S., Samulski, K., Campbell, D., Bayley, H. S. and Sinclair, J. C. (1983): Energy balance and nitrogen balance in growing low birthweight infants fed human milk or formula. Pediatr. Res. 17, 891-898.

Wilson, J. H. and Cudd, T. A. (1990): Common gastrointestinal diseases. In Equine Clinical Neonatology. Eds. A. M. Koterba, W. H. Drummond, P. C. Kosch. pp. 412-430

Wilson, D. C. and McClure, G. (1994): Energy requirements in sick preterm babies. Acta Paediatr. Suppl. 405, 60-64.

\section{Acknowledgements}

The authors thank P. Gorton, J. Osbourne and R. Cash for assays. This work was funded by the Horserace Betting Levy Board.

\section{Jennifer C. Ousey \\ Nicola Holdstock \\ P. D. Rossdale}

Beaufort Cottage Stables

High Street

Newmarket

Suffolk CB8 8JS

UK

\section{A.J. McArthur}

Dept. of Physics

University of the South Pacific

Suva

FIJI 